Notes

\title{
"FREEDOM OF" OR "FREEDOM FROM"? THE ENFORCEABILITY OF CONTRACTS AND THE INTEGRITY OF THE LLC
}

\author{
LEIGH A. BACON
}

\section{INTRODUCTION}

The sudden growth of limited liability company (LLC) legislation in the past ten years has been accompanied by a corresponding amount of scholarship dedicated to the logistics, concerns, and implications of the limited liability company. ${ }^{1}$ Most legal scholarship has examined the potential liability and the scope of the fiduciary duty of the members of an LLC. ${ }^{2}$ At issue in this Note is not the extent to which the members of an LLC owe duties to it or to each other but rather the extent to which the LLC is independent of its members. LLC legislation and case law expressly serve the principles of freedom of contract. Preserving the freedom of members

Copyright (C) 2001 by Leigh A. Bacon.

1. The limited liability company and the limited liability partnership (LLP) are both alternative business entities. The LLC provides limited liability to its members as well as the favorable pass-through tax treatment generally reserved for partnerships. Robert R. Keatinge et al., The Limited Liability Company: A Study of the Emerging Entity, 47 Bus. LAw. 375, 380 (1992). The LLP, meanwhile, preserves partnership tax treatment and proves a degree of limited liability for general partners as well as limited partners. Wayne M. Gazur, The Limited Liability Company Experiment: Unlimited Flexibility, Uncertain Role, 58 LAW \& CONTEMP. ProBs. 135, 168-69 (Spring 1995).

2. E.g., Richard A. Booth, Fiduciary Duty, Contract, and Waiver in Partnerships and Limited Liability Companies, 1 J. SMALl \& EMERGING BUS. L. 55, 55 (1997) (advocating a flexible approach to the fiduciary duty of LLC members); William H. Copperthwaite, Jr., Limited Liability Companies: The Choice for the Future, 103 CoM. L.J. 222, 236-37 (1998) (evaluating the benefits of the LLC form and noting that "the LLC organized in one state is constitutionally entitled to enter other states for purposes of interstate commerce, and those other states may not enact laws which unduly burden the LLCs ability to engage in interstate commerce"); Gazur, supra note 1, at 160-62 (discussing which fiduciary standards are appropriate by reviewing the various LLC management scenarios). 
to contract with one another as to the operation of the LLC, however, can occur at the expense of the LLC.

The law recognizes the LLC as an entity that has protected rights, at least for some purposes. ${ }^{3}$ This Note examines whether this status implies that, when executing agreements, the members of an LLC do not bind the LLC itself. It argues that courts should consider the separate entity characteristics of an LLC when considering whether to enforce against it an agreement to which it is not a party. Part I introduces two recent holdings that advance opposite conclusions as to whether an LLC should be bound by an arbitration and choice-of-forum clause in its operating agreement when it was not itself a signatory to the agreement. It then examines what effect the policies favoring arbitration have on the enforceability of arbitration clauses and argues that, notwithstanding freedom-ofcontract principles, an arbitration clause should not be enforced against a nonparty, even where that nonparty is an LLC. Part II suggests that comparing the LLC to the corporation might be more appropriate than comparing it to the partnership, and applies citizenship and internal-affairs-doctrine analyses to the LLC to demonstrate that the LLC can be considered a separate entity whose interests should be balanced against freedom-of-contract principles. Part III proposes that while providing for freedom of contract in LLC agreements might attract would-be members to form an LLC in a state that exalts such freedom in its LLC legislation, a state court system's refusal to respect the independence of an LLC might counter any such lure. The Note concludes that freedom of contract does not necessarily justify enforcing a contract against an LLC when it is not a party to the contract and that enforcement of such a contract could harm both the LLC and the state enforcing the contract.

\section{Whose FreEdom of CONTRACT DoEs LLC LAW PROTECT?}

Applying freedom-of-contract principles should require a preliminary determination that a contract among the parties does in fact exist and, in turn, a determination of the parties' identities. As uncontroversial as that proposition might seem, in light of the

3. For example, many LLC statutes allow the LLC to bring a suit and to enforce contribution pledges from its members. E.g., CAL. CORP. CODE $§ 17,201$ (West Supp. 1999); Del. Code ANN. tit. 6, § 18-502(a) (1993); N.Y. LtD. LiAB. Co. LAW § 502 (McKinney 19992000). 
decisions in Elf Atochem North America, Inc. v. Jaffari ${ }^{4}$ and Bubbles \& Bleach, L.L.C. v. Becker, ${ }^{5}$ its application to LLC law is not straightforward. In both cases courts applied standard principles of freedom of contract to similar fact patterns. The courts reached opposite conclusions, however, concerning whether an LLC's failure to sign an operating agreement that contains an arbitration clause and a choice-of-forum clause should matter when all of the LLC members signed the agreement. In Bubbles \& Bleach, the United States District Court for the Northern District of Illinois held that an LLC was not bound by such an agreement. ${ }^{6}$ In Elf Atochem, by contrast, the Delaware Supreme Court held that an LLC was bound to an agreement among, and signed by, its members. ${ }^{7}$ To the extent that freedom of contract protects the interests of the contracting parties, the discrepancy between the two cases largely results from the courts' divergence as to when and whether an LLC is an entity whose integrity must be respected. Comparing an LLC with other business forms suggests not only that an LLC does in fact merit consideration as an independent entity ${ }^{8}$ but also that a state has an interest in having the affairs of domestic LLCs resolved in its courts, applying its law. Principles of conflict of laws, citizenship, and the internal affairs doctrine likewise shed light on the interest that both an LLC and its state of formation have in the LLC's status as an independent entity.

\section{A. Two Cases, Two Conclusions}

To the extent that an LLC exists as an entity apart from its members, it should not itself be bound by an agreement among its members simply by virtue of their having signed it. Thus, an LLC's failure to sign an operating agreement that contains an arbitration clause and a choice-of-forum clause should matter even if all the LLC members signed the agreement. The Bubbles \& Bleach court reached exactly this conclusion; the Elf Atochem court did not. These cases present the conflict between protecting the LLC as an independent entity and preserving the principles of freedom of contract.

\footnotetext{
4. 727 A.2d 286 (Del. 1999).

5. No. 97 C 1320, 1997 WL 285938 (N.D. Ill. May 23, 1997).

6. Id. at $* 6$.

7. Elf Atochem, 727 A.2d at 287.

8. See infra Part II.

9. See infra Part II.B.2.
} 
Elf Atochem involved a derivative claim brought by Elf Atochem North America, Inc., a member of Malek LLC. The complaint alleged that Cyrus A. Jaffari, another member of the LLC, had breached his fiduciary duty to Malek LLC, pushed the LLC to virtual insolvency by withdrawing funds for personal use, interfered with its business opportunities, and tortiously interfered with business relations. ${ }^{10}$ Malek LLC was formed in Delaware by Elf Atochem North America, Inc., a Pennsylvania corporation, Jaffari, and Malek, Inc., of which Jaffari was CEO. ${ }^{11}$ The three parties entered into a series of agreements providing for the operation and governance of Malek LLC. ${ }^{12}$ The sticking point of the Elf Atochem case was an arbitration provision in the LLC agreement, which was signed by Elf Atochem, Jaffari, and Malek, Inc. ${ }^{13}$ The arbitration clause provided that any controversy arising out of the agreement, the interpretation of any of its provisions, or the action of any member under the agreement had to be submitted to arbitration in San Francisco. ${ }^{14}$ Another clause in the LLC agreement similarly provided that all members consented to exclusive jurisdiction of California in any claim arising out of the agreement. ${ }^{15}$ The distribution agreement entered into by Elf Atochem and Malek LLC, in contrast, contained neither an arbitration nor a choice-of-forum provision. ${ }^{16}$ In evaluating Elf Atochem's derivative claim, the Delaware Supreme Court held that Malek LLC was bound by the arbitration and choice-of-forum provisions, ${ }^{17}$ even though it was not a signatory to them.

The facts of Bubbles \& Bleach, LLC v. Becker were similar to those of Elf Atochem. ${ }^{18}$ The operating agreement of Bubbles \& Bleach, LLC contained an arbitration and choice-of-forum clause that selected Wisconsin law. ${ }^{19}$ Members Faye Becker and Richard Ross,

\footnotetext{
10. Elf Atochem, 727 A.2d at 289.

11. Id. at 288.

12. Id. Delaware LLC law allows the certificate of formation to be filed before the formation of the LLC agreement. DeL. CodE ANN. tit. 6, § 18-201(d) (1993). The agreement becomes effective as of the time the certificate is filed. Id. The Elf Atochem court characterized the certificate of formation as "the first statutory step in creating the LLC as a separate legal entity." Elf Atochem, 727 A.2d at 288.

13. Id. at $288-89$.

14. Id. at 288 .

15. Id. at $288-89$.

16. Id. at 288. The distribution agreement provided that Elf Atochem would be the exclusive distributor for Malek LLC and Jaffari would be the manager for Malek LLC. Id.

17. Id. at 287.

18. No. 97 C 1320, 1997 WL 285938, at*1-3 (N.D. Ill. May 23, 1997).

19. Id. at *4.
} 
the president of member Bilger Corporation, were signatories to the agreement. ${ }^{20}$ Bubbles \& Bleach, LLC brought suit against Becker for breach of fiduciary duty, fraud, and conversion, as well as other claims. ${ }^{21}$ In allowing the suit to proceed in court, the district court held that Bubbles \& Bleach, LLC was not bound by the arbitration and choice-of-forum clauses, because it was not a party to them. ${ }^{22}$

\section{B. The Impact of Pro-Arbitration Policies on the Elf Atochem and Bubbles \& Bleach Decisions}

Both the Elf Atochem and Bubbles \& Bleach courts had to consider the enforceability of contractual arbitration provisions against an LLC in light of policies favoring arbitration. The operating agreements of the LLCs in both cases contained provisions subjecting claims arising out of the agreements to arbitration. ${ }^{23}$ The Elf Atochem court viewed the arbitration provision in the Malek LLC operating agreement as being in line with the state policy favoring methods of alternative dispute resolution, including arbitration. ${ }^{24}$ It then determined that the purpose of encouraging arbitration outweighed the Delaware LLC Act's purposes for vesting the Court of Chancery with jurisdiction. ${ }^{25}$

DMS Properties-First, Inc. v. P.W. Scott Associates, Inc. ${ }^{26}$ raises some interesting points about the scope of the state's pro-arbitration policy, however. In $D M S$, the Delaware Supreme Court held that the Court of Chancery had erred in upholding an arbitrator's determination of the issue of arbitrability. ${ }^{27}$ The Court of Chancery in the DMS case had considered whether to vacate an arbitration

\footnotetext{
20. Id.

21. Id. at $* 3$.

22. Id. at $* 6$

23. See supra notes $13-22$ and accompanying text.

24. Elf Atochem, 727 A.2d at 292.

25. Id. at 295-96. Chapter 57 of title 10 of the Delaware Code contains the state provisions on arbitration. Section 5701 of title 10 provides, in part, that "[a] written agreement to submit to arbitration any controversy existing at or arising after the effective date of the agreement is valid, enforceable and irrevocable, save upon such grounds as exist at law or in equity for the revocation of any contract.” DEL. CODE ANN. tit. 10, § 5701 (1975). The Federal Arbitration Act, meanwhile, provides that "[a] written provision in any ... contract... to settle by arbitration a controversy thereafter arising out of such contract... shall be valid, irrevocable, and enforceable, save upon such grounds as exist at law or in equity for the revocation of any contract." 9 U.S.C. $§ 2$ (1994). The purpose of the Federal Arbitration Act is "to place arbitration agreements upon the same footing as other contracts." Gilmer v. Interstate/Johnson Lane Corp., 500 U.S. 20, 24 (1991).

26. 748 A.2d 389 (Del. 2000).

27. Id. at 393 .
} 
panel's determination that there was no valid agreement to arbitrate between the plaintiff, DMS, and the defendant, Scott Associates. ${ }^{28}$ The president of Scott Associates and Dennis Salter, of the Delaware corporation Holcomb \& Salter, had signed an arbitration agreement to cover a specific building project. ${ }^{29}$ Salter used DMS as the principal entity through which the project proceeded. ${ }^{30}$ Salter signed the agreement on behalf of Holcomb \& Salter. ${ }^{31}$ DMS was neither mentioned in the agreement nor later substituted as a party for Salter or for Holcomb \& Salter. ${ }^{32}$

The Vice Chancellor confirmed the arbitrator's determination that no valid agreement to arbitrate existed between DMS and Scott. In so doing, the Vice Chancellor noted that "[h]ad Scott lost the issue before the arbitrators and had DMS obtained an award against it, Scott could have sought to vacate the award" under section 5714 of title 10 of the Delaware Code, which provides that a party may move to vacate an arbitration award on the grounds that " $[\mathrm{t}]$ here was no valid arbitration agreement." ${ }^{, 33}$ The Vice Chancellor agreed that there was no binding agreement to arbitrate between DMS and Scott and cited the lack of any writing that documented the creation of a new contract between DMS and Scott as evidence of this conclusion. ${ }^{34} \mathrm{On}$ appeal, the Delaware Supreme Court held that the Court of Chancery erred in deferring to the arbitrator's determination of substantive arbitrability. ${ }^{35}$ The Supreme Court explained that whether the parties had agreed to arbitrate was a question for the court, not for the arbitrator. ${ }^{36}$ Specifically, the court noted:

A party cannot be forced to arbitrate the merits of a dispute, however, in the absence of a clear expression of such an intent in a valid agreement.... A party who has not agreed to arbitrate has a

\footnotetext{
28. Id. at 390 .

29. Id.

30. Id.

31. Id.

32. Id.

33. Del. Code Ann. tit. 10, § 5714(a)(5) (1999).

34. DMS Props.-First, Inc. v. P.W. Scott Assocs., No. CIV. A. 16450, 1999 WL 1261335, at *6 (Del. Ch. July 19, 1999).

35. DMS Props.-First, Inc., 748 A.2d at 393. "Substantive arbitrability" refers to whether the parties had agreed to arbitrate in the first place. Id. at 391.

36. Id. at 391. The Delaware Supreme Court conceded that whether the parties had agreed to arbitrate was a question for the court, not the arbitrator, unless the parties had clearly agreed to submit the question of arbitrability to arbitration. $I d$.
} 
right to have the merits of dispute adjudicated $a b$ initio by a court of competent jurisdiction. ${ }^{37}$

Noting that DMS had "not clearly agree[d] to submit the question of arbitrability to the arbitrators," 38 the Supreme Court held that "[t]he Court of Chancery should have received evidence regarding whether an agreement to arbitrate actually existed between DMS and Scott Associates and then independently determined the issue of nonarbitrability de novo. ${ }^{, 39}$ The Supreme Court remanded the case to the Court of Chancery to make this determination. ${ }^{40}$

Applying the logic expressed in DMS to the facts in Elf Atochem might have led to a different outcome, even in light of the policy favoring arbitration. In enforcing the arbitration and choice-of-forum provisions against Malek LLC, the Elf Atochem court emphasized that the LLC members were the "real parties in interest." ${ }^{41}$ In some respects, though, Dennis Salter, as president, was the "real party in interest" of DMS. The Court of Chancery nonetheless agreed with the arbitrator's determination that there was no binding agreement between DMS and Scott. ${ }^{42}$ And while the Delaware Supreme Court reversed the Court of Chancery's deferential upholding of the arbitrator's decision, the court expressly indicated that "DMS did not clearly agree to submit the question of arbitrability to the arbitrators." ${ }^{43}$ The higher court in $D M S$ also emphasized generally the importance of a clear expression of intent to arbitrate, even in light of the state policy favoring arbitration. ${ }^{44}$

The Bubbles \& Bleach court offered a more limited view of the policy favoring arbitration than the Elf Atochem court, similarly emphasizing the relevance of the parties' intent to agree to arbitrate. Most importantly, the court explained that while this policy applies to issues regarding the scope of the arbitration, it does not "extend to parties who never agreed to arbitrate in the first place." "45 The Bubbles \& Bleach court then considered the LLC's intent with

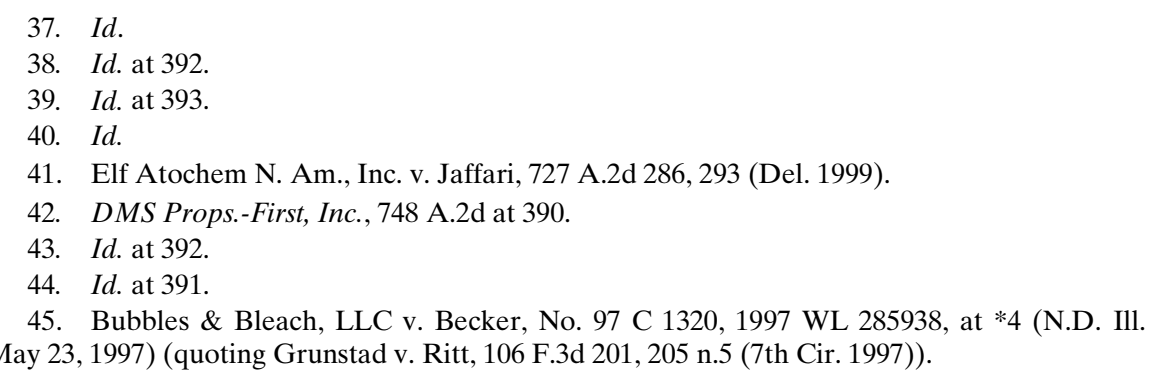


respect to the arbitration provisions. ${ }^{46}$ In so doing, the Bubbles \& Bleach court relied on the Seventh Circuit's ruling in Grunstad v. Ritt. ${ }^{47}$ In Grunstad, the Seventh Circuit faced the issue of whether a guarantor of a party to an agreement was bound by the arbitration clause of that agreement. ${ }^{48}$ The Seventh Circuit acknowledged that a nonsignatory guarantor could be bound by an arbitration provision where the guaranty incorporated the underlying agreement; however, mere reference to the main contract would not be sufficient to establish the guarantor's consent to arbitration. ${ }^{49}$ The Grunstad court suggested that specific language would be necessary to bind a guarantor to an arbitration clause in the underlying agreement. ${ }^{50}$

\section{Freedom of Contract and Noncontracting LLCs}

The analyses in these various cases all implicate principles of freedom of contract, mainly that a party should be free to consent, or not to consent, to certain contractual provisions. The degree of flexibility accorded to the drafters of LLC agreements highlights the importance of this principle. ${ }^{51}$ As the opinion in Elf Atochem demonstrates, promoting the freedom of such drafters to contract can occur at the expense of the LLC.

The Delaware Limited Liability Company Act provides that its policy is "to give the maximum effect to the principle of freedom of contract and to the enforceability of limited liability company agreements." ${ }^{, 52}$ Larry E. Ribstein and Robert R. Keatinge have described Delaware law as giving "much power" to LLC agreements. ${ }^{53}$ They explain that under Delaware law, the LLC agreement "should be able to control relations among those persons holding interests in the LLC, as well as the structure of the LLC

46. The Elf Atochem court did not consider the LLC's intent with respect to the agreement. Elf Atochem, 727 A.2d at 286. Nonetheless, one of the cases cited by the Elf Atochem court in support of the Delaware policy favoring arbitration stated that, while "[a]ny doubt as to arbitrability is to be resolved in favor of arbitration," SBC Interactive, Inc. v. Corporate Media Partners, 714 A.2d 758, 761 (citing Pettinaro Constr. Co. v. Harry C. Partridge, Jr., \& Sons, Inc., 408 A.2d 957, 962-63 (Del. Ch. 1979)), a court "will not compel a party to arbitrate ... absent a clear expression of such an intent." Id. at 761.

47. 106 F.3d 201 (7th Cir. 1997).

48. Id. at $202-03$.

49. Id. at 204 n. 4 .

50. Id. at 205 .

51. See infra notes $195-96$ and accompanying text.

52. Del. Code AnN. tit. 6, § 18-1101 (1999).

53. 1 LARRY E. Ribstein \& Robert R. KeAtinge, RibSTEIn \& KeAtinge on LlCs $\S 14.01[3][\mathrm{b}](1997)$. 
itself." ${ }^{54}$ The Uniform Limited Liability Company Act has likewise been interpreted as allowing an LLC to be fashioned almost entirely by the agreement of its members. ${ }^{55}$

It is not altogether surprising, then, that the Elf Atochem court characterized the LLC agreement exclusively as a contract of the members. Comparing LLCs to limited partnerships, the Elf Atochem court applied the following observation about limited partnerships (LP) to LLCs:

The Act's basic approach is to permit partners to have the broadest possible discretion in drafting their partnership agreements and to furnish answers only in situations where the partners have not expressly made provisions in their partnership agreement.... Once partners exercise their contractual freedom in their partnership agreement, the partners have a great deal of certainty that their partnership agreement will be enforced in accordance with its terms. $^{56}$

The Elf Atochem court insisted further that a member's agreement would only be invalid when it was inconsistent with mandatory statutory provisions and that such provisions were likely those intended to protect third parties, not the contracting members.

The Elf Atochem court did not treat an LLC itself as a third party warranting such protection, even where the LLC was not an express party to an LLC agreement. In fact, the Elf Atochem court did not consider Malek LLC an entity that would need to sign and be party to the agreement. In reference to the LLC agreement, the Elf Atochem court explained, "[i]t is the members who are the real

54. Id. § 14.01[3]. For example, section 18-306 permits an LLC agreement to impose penalties on managers or members who breach the agreement. DEL. CODE ANN. tit. 6, § 18-306. Section 18-108 authorizes the LLC agreement to include an indemnification provision. $I d$. § 18108. Section 18-402 allows the agreement to alter the default management provisions. Id. § 18402. Finally, section 18-106(b) provides:

A limited liability company shall possess and may exercise all the powers and privileges granted ... by its limited liability company agreement, together with any powers incidental thereto, including such powers and privileges as are necessary or convenient to the conduct, promotion or attainment of the business, purposes or activities of the limited liability company.

Id. $\S 18-106(\mathrm{~b})$.

55. Gazur, supra note 1 , at 144

56. Elf Atochem N. Am., Inc. v. Jaffari, 727 A.2d 286, 291 (Del. 1999) (quoting MARTIN I. Lubaroff \& Paul M. Altman, Delaware Limited Partnerships § 1.2 (1999)). Obviously, as applied to LLC agreements, this quotation makes sense only if "members" is substituted for "partners" and "LLC agreements" is substituted for "partnership agreements."

57. Id. at 292 . 
parties in interest. The LLC is simply their joint business vehicle." ${ }^{58}$ In discussing the validity of arbitration provisions in LLC agreements, the Elf Atochem court saw no reason why members could not alter the default jurisdictional provisions of the Delaware statute-which vest the Court of Chancery with jurisdiction over matters involving removing managers as well as interpreting and enforcing LLC agreements 5 -and "contract away their right" to bring suit in Delaware for purposes of convenience. ${ }^{60}$ While Elf Atochem involved a derivative suit brought by a member on behalf of Malek LLC, ${ }^{61}$ the Elf Atochem analysis raises a question as to whether the action would still have been subject to arbitration if Malek LLC had brought the suit on its own behalf. ${ }^{62}$ The court's analysis seems to suggest,

58. Id. at 293. Professors Ribstein and Keatinge likewise suggest that the primary parties to an LLC agreement are the members and that the definition of an LLC agreement under the Delaware statute mentions only members and assignees suggests that others are excluded as parties. RIBSTEIN \& KEATINGE, supra note 53, § 14.01[3][a].

59. Del. CODE ANN. tit. 6, §§ 18-110, 18-111 (1999).

60. Elf Atochem, 727 A.2d at 295.

61. Section 18-1001 provides:

A member ... may bring an action in the Court of Chancery in the right of a limited liability company to recover a judgment in its favor if managers or members with authority to do so have refused to bring the action or if an effort to cause those managers or members to bring the action is not likely to succeed.

Del. Code AnN. tit. 6, § 18-1001 (1999). The Elf Atochem court described the derivative suit as "a corporate concept grafted onto the limited liability form." Elf Atochem, 727 A.2d at 293. The court characterized the classification of Elf Atochem's suit as derivative as "irrelevant," reasoning first that Elf Atochem had contracted away its right to bring a derivative suit in Delaware and second that the agreement's arbitration and forum provisions did not distinguish between direct and derivative claims. $I d$. at 293-95.

62. Unlike Elf Atochem, in Bubbles \& Bleach the suit was initiated by the LLC. Given the very different analysis of the nature of LLC agreements offered by the Delaware Supreme Court in Elf Atochem, however, this precedent is not particularly helpful in predicting how the Delaware courts would view an LLC-initiated suit. Also, the Bubbles \& Bleach court did not have to balance its analysis with the concern that members would couch claims as derivative in order to avoid being bound by arbitration provisions in the agreement, a legitimate problem recognized by the Elf Atochem court.

Delaware law apparently provides that an LLC may be a party in an action for the breach of an LLC agreement. As Professors Ribstein and Keatinge point out, the Delaware Limited Liability Company Act contemplates that members and managers may, under the provisions of the LLC agreement, be subject to "specified consequences" upon its breach. RibSTEIN \& KeAtinge, supra note 53, § 14.01[3][e][iv] (citing Del. Code ANN. tit. 6, § 18306(1) (1999). Delaware law grants standing to an LLC in other types of actions; for example, section 18-603 provides that an LLC may recover damages from a resigning manager. DEL. CODE ANN. tit. 6, § 18-603 (1999) (prohibiting a member from resigning prior to the dissolution and winding up of the LLC unless specifically permitted in the LLC agreement). Furthermore, Delaware law expressly allows derivative actions to be brought on behalf of an LLC. Id. $\S 18-$ 1001, 18-1002. 
however, that an LLC's interest in not having its agreement enforced against it is not enough to counteract freedom-of-contract principles. ${ }^{63}$

Both the decision in Bubbles \& Bleach, LLC v. Becker and Ribstein \& Keatinge on LLCs suggest that an LLC should not be subject to arbitration or choice-of-forum provisions in an agreement to which it is not a party. In discussing the possibility of enforcing an agreement against nonmember managers, for example, Ribstein and Keatinge argue that consequences authorized by an agreement should not be enforceable against a manager who has not assented to the agreement, according to contract-law principles. ${ }^{64}$ They also note that an agreement among fewer than all of the members should not affect the management or financial rights of a member who is not a party to the agreement. ${ }^{65}$

Bubbles \& Bleach, meanwhile, clearly holds that a provision in an LLC agreement is not enforceable against the LLC when the LLC is not a party to the agreement. ${ }^{66}$ Unlike the Elf Atochem court, the Bubbles \& Bleach court analyzed the agreement based on the assumption that an LLC is an entity: "[I]t is this characteristic of limited liability companies-their distinct legal existence as an entity apart from their constituent members-which allows them to shield their members from personal liability and distinguishes them from both general and limited partnerships. ${ }^{167}$ The court then inquired as to whether the agreement "unambiguously express[ed] [the LLC's] intent to be personally bound by the arbitration clause. ${ }^{, 68}$ The district

63. Advocates of applying contract principles to corporate law have intimated that the identity of the corporate form is a matter of convenience and not of importance. See generally FrANK H. EASTERBROOK \& DANIEL R. FisCHEL, THE ECONOMIC STRUCTURE OF CORPORATE LAW 8-15 (1991) (observing that the essence of a corporation's personhood is the combination of the entity's contracts and the individual actors who participate in entity transactions). This Note argues that applying concepts of corporate identity, namely the internal affairs doctrine and the determination of citizenship, to LLC law suggests that the identity of the LLC is at least as much of a reality as that of the corporation. Furthermore, given the potential interest of a state in the development of its LLC business and the internal affairs of its LLCs, the identity of the LLC is a matter of concern. See infra Part III.

64. Ribstein \& KeAtinge, supra note 53, § 14.01[3][a]. At the same time, Professors Ribstein and Keatinge note that a properly drafted LLC agreement would not be unenforceable merely by reason of its not having been signed by a person admitted as a member or an assignee. Id. § 14.01[3][c] (citing DEL. CODE ANN. tit. 6, § 18-101(7)(b) (1999), which provides that a limited liability company agreement "[s]hall not be unenforceable by reason of its not having been signed by a person being admitted as a member or becoming an assignee").

65. RIBSTEIN \& KEATINGE, supra note 53, § 4.16.

66. Bubbles \& Bleach, LLC v. Becker, No. 97 C 1320, 1997 WL 285938, at *6 (N.D. Ill. May 23, 1997).

67. Id. at $* 4$.

68. Id. 
court determined that Wisconsin law, under which Bubbles \& Bleach, LLC was formed, does not intend operating agreements to bind LLCs, "entities distinct from their constituent members." noted further that the Bubbles \& Bleach, LLC agreements did not demonstrate that the member-signatories had signed on behalf or in the name of the LLC. It accepted that, even though the agreements governed some aspects of the LLC's operation, the LLC was not necessarily bound by the arbitration and choice-of-forum provisions in them. ${ }^{70}$ Other state statutes might support a similar interpretation of LLC agreements as that offered by the Bubbles \& Bleach decision. In fact, statutes in some states explicitly define an LLC as "an entity."

While the recognition of an LLC as a separate entity for purposes of limited liability could carry over to an analysis as to whether it would be bound by provisions in an operating agreement, as in Bubbles \& Bleach, the Elf Atochem court identified a potential problem with such an analysis. Specifically, the Elf Atochem court did not want to encourage members to couch their claims as derivative in order to avoid arbitration and choice-of-forum provisions and claim subject matter jurisdiction in the Court of Chancery. ${ }^{72}$ Such a tactic would conflict with a policy favoring arbitration. ${ }^{73}$ A hard-and-fast rule that, for the purposes of interpreting LLC agreements, the

69. Id. In support of its reasoning, the Bubbles \& Bleach court cited the statutory definition of an LLC operating agreement, which provides that an "operating agreement" is a written agreement "among all of the members as to the conduct of the business of a limited liability company and its relationships with its members." Id. at *4. Delaware law defines an LLC agreement as "any agreement... of the ... members as to the affairs of a limited liability company and the conduct of its business." DEL. CODE ANN. tit. 6, § 18-101(7) (1999).

70. Bubbles \& Bleach, 1997 WL 285938, at $* 5$.

71. E.g., KAN. STAT. ANN. § 17-7603(b) (1995) (“A limited liability company formed under this act shall be a separate legal entity and shall not be construed as a corporation."); VA. CODE ANN. § 13.1-1002 (Michie 1999) (defining an LLC as "an entity that is an unincorporated association"). The Uniform Limited Liability Act (ULLCA) similarly states that "[a] limited liability company is a legal entity distinct from its members." UNIF. LTD. LIAB. ACT § 201, 6A U.L.A. 443 (1995). The ULLCA has been enacted, with some modifications, in Alabama, Hawaii, South Carolina, South Dakota, Vermont, and West Virginia. ALA. CoDE §§ 10-12-1 to -12-61 (1994); Haw. Rev. STAT. ANN. \$§ 428-101 to -1302 (Michie 1997); S.C. CoDE ANN. $\S \S 33-44-101$ to -44-1207 (West Supp. 1999); S.D. CoDIFIED LAWs $\S \S 47-34 \mathrm{~A}-101$ to -34A-1207 (Michie Supp. 1999); VT. STAT. ANN. tit. 11, §§ 3001-3162 (1997); W. VA. CODE §§ 31B-1-101 to $-1-1306$ (1996 \& Michie Supp. 1999). Five of these states contain language similar to section 201 of the ULLCA. HAw. REV. STAT. ANN. § 428-201 ("A limited liability company is a legal entity distinct from its members."); S.C. CODE ANN. § 33-44-201 (same); S.D. CODIFIED LAWs § 4734A-201 (same); Vt. STAT. ANN. tit. 11, § 3021 (same); W. VA. CoDE §31B-2-201 (same).

72. Elf Atochem N. Am., Inc. v. Jaffari, 727 A.2d 286, 296 (Del. 1999).

73. Id. at 295 . 
members of the LLC and the LLC itself are one and the same is equally problematic, however. As the opinion in Bubbles \& Bleach noted, "such a rule necessarily assumes (or requires) that the LLC can enforce the agreement against the members. To allow enforcement by the LLC seems inconsistent with the basis for the rule in the first place, that is, that the members are the LLC and vice versa." ${ }^{74}$ Regrettably, this inconsistency was not addressed by the court in Elf Atochem v. Jaffari.

\section{Should FreEdom-OF-CONTRACT PRINCIPLES PROTECT CONTRACTUAL CHOICE OF FORUM?}

An agreement to arbitrate before a specified tribunal is, in effect, a specialized kind of forum-selection clause that posits not only the situs of suit but also the procedure to be used in resolving the dispute. $^{75}$

The Supreme Court has stated that any doubt as to the scope of arbitrable issues should be resolved in favor of arbitration. ${ }^{76}$ One argument in favor of enforcing choice-of-law and choice-of-forum provisions generally is that doing so reduces uncertainty at the time of contracting, so that the parties know to what standard of conduct they should conform. ${ }^{77}$ The Delaware Supreme Court enforced the arbitration and choice-of-forum provisions at issue in Elf Atochem, even though the LLC involved was not an express party to those provisions. In so doing, the Elf Atochem court treated the LLC as a partnership, holding that an LLC does not exist independently from its members for purposes of enforceability of the provisions of the LLC agreement.

While the LLC certainly does resemble a partnership in certain respects, the partnership analogy does not capture the breadth of the LLC. The LLC also possesses characteristics of a corporation, which has consistently been recognized as a distinct legal entity. As a

74. Bubbles \& Bleach, LLC v. Becker, No. 97 C 1320, 1997 WL 285938, at *5 (N.D. Ill. May 23, 1997).

75. Scherk v. Alberto-Culver Co., 417 U.S. 506, 519 (1974); see also Mitsubishi Motors Corp. v. Soler-Chrysler Plymouth, Inc., 473 U.S. 614, 630 (1985) (quoting this passage from Scherk); Simitar Entm't, Inc. v. Silva Entm't, Inc., 44 F. Supp. 2d 986, 996 (D. Minn. 1999) (“In a practical sense, an arbitration agreement operates as no more than a specialized choice-offorum provision, which has the effect of identifying the 'situs of the suit,' as well as the procedures that govern its resolution.").

76. Moses H. Cone Mem'l Hosp. v. Mercury Constr. Corp., 460 U.S. 1, $24-25$ (1983).

77. Larry E. Ribstein, Choosing Law by Contract, 18 J. CoRP. L. 245, 253 (1993). 
distinct legal entity, a corporation has interests that can be affected by a determination of which law governs particular disputes. This part compares the LLC with the corporation to suggest that the independence of the LLC itself should be considered before it is subjected to a particular forum or law. This part also examines how conflict-of-laws, citizenship, and internal affairs principles determine the law governing other types of business associations and could be used to determine which law should govern an LLC.

\section{A. The Partnership Analogy}

The LLC is often compared with a partnership. ${ }^{78}$ Application of partnership law, as presented by the Restatement provisions on choice of law, suggests that an LLC should not expect to have its affairs resolved by the laws of its formation state. ${ }^{79}$ The partnership analogy is not a perfect one, however. Australian law, for example, explicitly recognizes a distinction between its equivalent of a partnership and that of a limited liability company. ${ }^{80}$ Imperfections in the comparison between a partnership and an LLC, in turn, demonstrate the usefulness of comparing the LLC to other business forms, principally the corporation.

1. Strengths of the Analogy and the According Application of Contract Principles. The limited liability company is often compared to a partnership. Many state LLC laws contain provisions originated, at least formally, from partnership law. ${ }^{81}$ Courts and scholars alike have especially focused on the limited partnership as an analogy for the LLC. ${ }^{82}$ The Elf Atochem court endorsed this analogy in noting

78. Many scholars and courts, including the Elf Atochem court, have noted certain similarities between the LLC and the partnership. E.g., Gazur, supra note 1, at 135-36 ("[M]ost states' LLC laws utilize, in varying degrees, provisions clearly of partnership origin."); Keatinge et al., supra note 1, at 396-403 (comparing LLCs to both limited and general partnerships).

79. See infra note 93 and accompanying text.

80. See infra notes 101-07 and accompanying text.

81. Gazur, supra note 1 , at 135 .

82. E.g., Cosgrove v. Bartolotta, 150 F.3d 729, 731 (7th Cir. 1998) (finding that an LLC is like a limited partnership for purposes of citizenship in diversity jurisdiction); Weber v. King, 110 F. Supp. 2d 124, 131-32 (E.D.N.Y. 2000) (relying on an analogy to limited partnerships to permit plaintiffs to commence a derivative suit on behalf of an LLC); Interactive Servs. Inc. v. Vista Net L.L.C., 1999 WL 1186429 (N.D. Ill. Dec. 10, 1999) (finding that an LLC is like a limited partnership for purposes of citizenship in diversity jurisdiction); Fallany O. Stover \& Susan Pace Hamill, The LLC Versus LLP Conundrum: Advice for Businesses Contemplating the Choice, 50 ALA. L. REV. 813 (1999) (providing an extensive comparison of LLCs and limited partnerships). 
that the Delaware Limited Partnership Act served as a model for the state's Limited Liability Company Act, describing the form and language of the two acts as "almost identical." Atochem court emphasized that freedom of contract underlies both the state LP and LLC Acts and that the LLC Act treats a member of an LLC much like a limited partner is treated under the LP Act. ${ }^{84}$

If an LLC is assumed to be similar to a limited partnership, the Restatement (Second) of Conflict of Laws suggests that a determination of the validity of choice-of-law provisions in an LLC agreement should depend on principles of contract law. The Restatement provides that " $[\mathrm{t}]$ he rights and duties owned by partners to each other are determined by the local law of the state which, with respect to the particular issue, has the most significant relationship to the partners and the transaction under the principles stated" in section six. ${ }^{85}$ The rules in sections 187 and 188 in turn determine which state's law is the "most significant."

Section 188 dictates which law should govern the rights and duties of the parties to a contract in the absence of an effective choice of law by the parties. It provides that these rights and duties be determined by the local law of the state that has the "most significant relationship" to the parties and the transaction under the principles of section six. ${ }^{87}$ Section six, in turn, states that a court will follow a statutory directive of its own state on choice of law, ${ }^{88}$ but that, where such a directive is lacking, a court should consider the following factors as relevant to the choice of the applicable law:

(a) the needs of the interstate and international systems,

(b) the relevant policies of the forum,

(c) the relevant policies of other interested states and the relative interests of those states in the determination of the particular issue,

(d) the protection of justified expectations,

83. Elf Atochem N. Am., Inc. v. Jaffari, 727 A.2d 286, 290 (Del. 1999). In their presentation of the Delaware Limited Liability Company Act, Professors Ribstein and Keatinge include a table denoting those provisions of the statute that derive from the state Revised Uniform Limited Partnership Act. RiBSTEIN \& KeAtinge, supra note 53, § 14.02, tbl. 14.1.

84. Elf Atochem, 727 A.2d at 290 (citing Martin I. Lubaroff \& Paul M. Altman, Delaware Limited Liability Companies, in Delaware LAW OF CORPORATIONS \& Business ORGANIZATIONS, §§ 20.3, 20.4 (R. Franklin Balotti \& Jesse A. Finkelstein eds., 1998)).

85. RESTATEMENT (SECOND) OF CONFLICT OF LAWS § 294 (1971).

86. Id. $\S \S 187-88$.

87. Id. $\S 188(1)$.

88. Id. § 6(1). 
(e) the basic policies underlying the particular field of law,

(f) certainty, predictability and uniformity of result, and

(g) ease in the determination and application of the law to be applied. $^{89}$

Section 188 delineates certain contacts to be taken into account when applying these principles to situations in which parties have not made an effective choice of law. Under section 188, a determination of which law should govern requires consideration of "(a) the place of contracting, (b) the place of negotiation, (c) the place of performance, (d) the location of the subject matter of the contract, and (e) the domicil, residence, nationality, place of incorporation and place of business of the parties." $" 90$

Section 187, meanwhile, covers those situations in which contracting parties have chosen a particular law. It provides that the chosen law should be applied unless the chosen state has "no substantial relationship" to the parties or to the transaction and "there is no other reasonable basis for the parties' choice" $"$ or unless application of the chosen law would be contrary to "a fundamental policy of a state which has a materially greater interest than the chosen state in the determination of the particular issue." ${ }^{92}$

To the extent that partnership relations are covered by contractual principles of conflict of laws (as provided in section 294 of the Restatement), a partnership operating outside its formation state "cannot be assured of being governed by its formation-state rules." 93 Equating an LLC with a partnership would therefore suggest that Malek LLC, the LLC involved in the dispute in Elf Atochem, should not necessarily have expected the issue to be resolved in Delaware, where it was formed and where the action was actually filed. Given this consideration, forcing Malek LLC to abide by contractual provisions and have its dispute resolved in arbitration in California seems fairly reasonable-even though the LLC was not an express party to those contracts.

\footnotetext{
89. Id. §6(2).

90. Id. $\$ 188(2)$.

91. Id. $\S 187(2)(\mathrm{a})$.

92. Id. § 187(2)(b).

93. Ribstein, supra note 77, at 269.
} 
2. Imperfections in the Partnership Analogy. The analogy between a limited liability company and a partnership, however, is not a perfect fit. Although the LLC is similar to the partnership, "in many respects aside from the limited liability factor, the analogy is weakened by the greater range of the LLC." in a partnership manner or in a corporate manner, characterized by a greater degree of separation between ownership and management. ${ }^{95}$ In Delaware, for example, an LLC agreement can " $[a] t$ minimum" govern any subject or establish any arrangement properly treated in a partnership agreement. ${ }^{96}$ The Delaware LLC is an amalgam of limited partnership and corporate characteristics. ${ }^{97}$ As described by the Elf Atochem opinion, it "combines corporate-type limited liability with partnership-type flexibility and tax advantages." " Importantly, as identified by the Bubbles \& Bleach court, ${ }^{99}$ the LLC, unlike a partnership, exists as a separate entity apart from its members, at least for purposes of limited liability. ${ }^{100}$

Analysis of the law of Australia, another common law jurisdiction, likewise suggests the imperfections of the partnership analogy. Australian law draws a clear distinction between limited liability companies and partnerships. An Australian limited liability company is an independent entity but is statutorily bound by the

94. Gazur, supra note 1 , at 156

95. Id. at $156-57$.

96. RIBSTEIN \& KEATINGE, supra note 53, § 14.01[3] (emphasis added).

97. Id. § 14.01[6][a]; see also James G. Leyden, Jr., A Key State’s Approach to LLCs, BUS. LAW TODAY, May-June 2000, at 51 ("The Delaware Limited Liability Company Act ... is modeled on the state's well-accepted limited partnership statute.... In addition, several provisions from the Delaware General Corporation Law have been incorporated into the DLLC Act.").

98. Elf Atochem N. Am., Inc. v. Jaffari, 727 A.2d 286, 290 (Del. 1999).

99. Bubbles \& Bleach, LLC v. Becker, No. 97 C 1320, 1997 WL 285938, at *4 (N.D. Ill. May 23, 1997)

100. In considering whether interests in an LLC constituted securities for purposes of the federal securities laws, the United States District Court for the District of Delaware distinguished the LLC from both the general and limited partnership:

The primary differences between LLCs and general partnerships are that members of LLCs are entitled to limited liability, and . . . the members of the LLC may be less involved in the management of the enterprise than partners in a general partnership.... In comparison with limited partnerships, the Delaware Limited Liability Company Act permits a member in an LLC to be an active participant in management and still to retain limited liability.

Great Lakes Chem. Corp. v. Monsanto Co., 96 F. Supp. 2d 376, $391-92$ (D. Del. 2000). The court concluded that the presumptions about partnerships applied in securities cases did not apply to LLCs and instead held that the terms of a particular LLC's operating agreement would determine whether interests in that LLC were securities. Id. at 392. 
terms of its agreement. An Australian company is a common law corporation that has been registered under part 2 of the Corporations Law. ${ }^{101}$ A common law corporation is "a legal device by which legal rights, powers, privileges, immunities, duties, liabilities and disabilities may be attributed to a fictional entity equated for many purposes to a natural person." ${ }^{102}$ A limited liability company, in turn, is a company whose members have limited liability. ${ }^{103}$ The concept of a company as a legal entity separate from the legal persons who are its members is important in Australian law; ${ }^{104}$ it is often the reason why a company is chosen as a vehicle for business. ${ }^{105}$ An Australian company's constitution (which serves as a memorandum of association), ${ }^{106}$ however, operates like a contract under seal between the company and each member and between the company and each eligible officer, as well as between the members. ${ }^{107}$ In this respect, while an Australian limited liability company is clearly an independent entity, by statute, it is bound by the terms of its agreement.

\section{B. The Corporation Analogy}

Whether a limited liability company formed under state law should be treated as a partnership or as a corporation is not so clear. To the extent that the LLC enjoys corporate-type treatment for purposes of liability, the application of corporate-type treatment for purposes of governing law merits consideration. ${ }^{108}$ Principles of

101. H.A.J. FORD \& R.P. AUSTIN, FORD AND AUSTIN'S PRINCIPLES OF CORPORATIONS LAW $\$ 1.050$ (7th ed. 1995).

102. Id.

103. Id. $\$ 1.080$.

104. Id. $\$ 4.140$ (describing the "separate entity doctrine").

105. Id. $\S 1.070$ ("The separate legal personality of a company is usually the explanation as to why a company has been chosen for the conduct of some business enterprise or social organisation.").

106. Id. § 6.010:

A company's constitution consists of its memorandum of association and its articles. In the process of incorporation the memorandum of association provides the ASC [Australian Securities Commission] with evidence that associated persons desire the ASC to incorporate them as a registered company. But it also provides some of the terms of upon which [sic] the incorporators became associated. Other terms are provided by the articles.

107. Id. $\S 6.030$.

108. A Delaware Superior Court has, in fact, held that an LLC should be treated as a corporation such that it is subject to the court rule requiring a corporation to be represented by legal counsel in litigation. Poore v. Fox Hollow Enters., No. 93A-09-005, 1994 WL 150872, at *2 (Del. Super. Ct. Mar. 29, 1994) ("Ultimately, regulation of the practice of law rests in the Delaware Supreme Court, not the legislature. The underlying purpose of the rule prohibiting 
citizenship and the internal affairs doctrine often determine whether a particular court has jurisdiction over a corporation. These principles could likewise be used to analyze whether a court should insist on exercising jurisdiction over an LLC and thereby preserve the state's and the LLC's interest in the LLC as an entity.

Citizenship analysis indicates that treating an LLC in the same way as a corporation is within the power of the legislature..$^{109}$ Historical consideration of the citizenship of common law entities further suggests that such treatment might be proper. ${ }^{110}$

Application of the internal affairs doctrine also demonstrates the possibility of corporate-type treatment of the LLC. The internal affairs doctrine serves interests that are important in the LLC as well as the corporate context; ${ }^{111}$ it benefits not only the entity and its beneficial owners ${ }^{112}$ but also the state of formation. ${ }^{113}$

1. Citizenship Analysis. A corporation does not enjoy status as a citizen within the meaning of the Privileges and Immunities Clause of the United States Constitution. ${ }^{114}$ For purposes of determining federal diversity jurisdiction, however, a corporation is treated as a citizen of the state in which it is incorporated. ${ }^{115}$ The Supreme Court declined to

the appearance of a corporation by anyone other than a member of the Delaware Bar also applies to the representation of Limited Liability Companies.") In deciding whether "a Limited Liability Company more closely resembles a partnership ... or a corporation," the Superior Court noted that "the interest of a member in the LLC is analogous to shareholders of a corporation." Id. at *1-2; cf. Elf Atochem, 727 A.2d at 293 ("It is the members [of an LLC] who are the real parties in interest. The LLC is simply their joint business vehicle.").

The United States District Court for the District of Massachusetts similarly treated an LLC as a corporation for purposes of section 1 of the Sherman Act. Fraser v. Major League Soccer, L.L.C., 97 F. Supp. 2d 130, 135 (D. Mass. 2000) (holding that in the context of the Sherman Act, "there is little reason to treat an LLC such as MLS differently from a corporation"). In holding that the defendant LLC was not subject to the Sherman Act, the court noted that the Sherman Act is "directed against contracts, combinations or conspiracies." Id. at 134. The court also pointed out that each LLC member's success was dependent upon the success of the LLC as a whole. Id. at 136.

109. See infra notes 141-43 and accompanying text.

110. See infra notes 130-39 and accompanying text.

111. See infra notes $174-83$ and accompanying text.

112. See infra notes 150,154 and accompanying text

113. See infra notes $146-49$ and accompanying text.

114. P. John Kozyris, The Limited Liability Company: Does It Exist Out-of-State? What Law Governs It?, 64 U. CIN. L. REV. 565, 565 (1996) (citing U.S. CONST. art. IV, § 2; id. amend. XIV, $\S 1$ ); see also Paul v. Virginia, 75 U.S. (8 Wall.) 168, 177 (1868) ("The term citizens . . applies only to natural persons, members of the body politic . . . not to artificial persons created by the legislature ....").

115. 28 U.S.C. $\$ 1332(\mathrm{c})(1)$ (1994). The federal statute provides that, for purposes of diversity jurisdiction, a corporation is a citizen of its state of incorporation and the state in which 
extend this citizenship rule to other business associations in Carden $v$. Arkoma Associates. ${ }^{116}$ Carden specifically held that a limited partnership is not a citizen of the state in which it is organized but rather of those states in which its partners are citizens. ${ }^{117}$ The Carden majority further required that both limited and general partners must be counted for purposes of calculating citizenship. ${ }^{118}$ To the extent that an LLC is analogous to a partnership, Carden suggests that an LLC is not a citizen of the state of its formation for purposes of diversity jurisdiction.

Lower courts have subsequently ruled that an LLC does not enjoy the same citizenship status as a corporation. The United States District Court for the District of Massachusetts, for example, stated that, with respect to diversity jurisdiction, "there is no justification for treating a limited liability company like a corporation." ${ }^{, 19}$ The United States District Court for the Western District of Michigan reached a similar conclusion, holding that, for purposes of diversity jurisdiction, an LLC is not a citizen of the state in which it is organized unless one of its members is a citizen of that state; the citizenship of an LLC is that of its members. ${ }^{120}$ Other jurisdictions have likewise declined to treat an LLC as a citizen of the state of which it was organized. ${ }^{121}$

The refusal to treat an LLC like a corporation for purposes of federal diversity jurisdiction enjoys some pre-Carden precedent. While relatively few states have recognized the limited partnership association, ${ }^{122}$ it is often considered the earliest precursor of the LLC. ${ }^{123}$ Specifically, in Great Southern Fire Proof Hotel Co. v. Jones, ${ }^{124}$ the Supreme Court held that a limited partnership association could not be considered a citizen under the jurisdictional rule for

\footnotetext{
its principal place of business is located. $I d$. The latter condition of jurisdiction is not central to this Note.

116. 494 U.S. 185,189 (1990).

117. Id. at $195-96$.

118. Id. (requiring that diversity jurisdiction in a suit by or against a limited partnership depends on the citizenship of "all the members" of the organization).

119. JMTR Enters., L.L.C. v. Duchin, 42 F. Supp. 2d 87, 94 (D. Mass. 1999).

120. Int'l Flavors \& Textures, L.L.C. v. Gardner, 966 F. Supp. 552, 554 (W.D. Mich. 1997).

121. E.g., Cosgrove v. Bartolotta, 150 F.3d 729, 731 (7th Cir. 1998); U.S.A. Seafood, L.L.C. v. Koo, No. 97-CV-1687, 1998 WL 765160, at*1 (S.D.N.Y. Oct. 30, 1998).

122. Michigan, New Jersey, Ohio, and Pennsylvania created the limited partnership association in the United States in the late nineteenth century and are among the few states that have statutes recognizing partnership associations. Keatinge et al., supra note 1, at 381-82.

123. E.g., id. at 381 (explaining that the current form of the LLC is based upon partnership associations).

124. 177 U.S. 449 (1900).
} 
corporations, even though the limited partnership association possessed "some of the characteristics of a corporation" and was considered a "corporation" by the law that created it. ${ }^{125}$ As such, the Great Southern holding contributes to the case law standing against treating an LLC like a corporation for purposes of federal diversity jurisdiction.

The fact that an LLC does not generally enjoy exactly similar citizenship status as a corporation might suggest that an LLC, as a separate entity, does not possess the same level of integrity as does a corporation. It also might suggest that a state in which an LLC is organized does not have the same interest in the affairs of a domestic LLC as it does in a domestic corporation. The Carden Court, however, expressly refrained from holding so broadly. The majority stated only that principles of judicial restraint mandated that the LP not be treated as a corporation for diversity purposes; it explicitly left room for the legislature to provide otherwise. ${ }^{126}$ Thus, even current citizenship analysis leaves room to argue that the LLC should enjoy independent entity status similar to that of a corporation. Although these decisions on their face indicate that, in the absence of a statute, LLCs do not enjoy the citizenship status of a corporation, sufficient ambiguity exists to suggest a justification for corporate-type treatment of the LLC.

First, some precedent exists that arguably supports treating the LLC more as an entity than as a conglomerate of its members for purposes of federal diversity jurisdiction. In General Atlantic Investments Ltd. v. Business Development Capital Limited Partnership-II, ${ }^{127}$ the United States District Court for the Southern District of New York treated a foreign LLC (one from another country as opposed to from another state) as a corporation for purposes of diversity jurisdiction and determined its citizenship based on the LLC's principal place of business. ${ }^{128}$ After Carden, however,

125. Id. at 456 .

126. Carden v. Arkoma Assocs., 494 U.S. 185, 197. The Carden majority noted that its holding could "validly be characterized as technical, precedent-bound, and unresponsive to policy considerations raised by the changing realities of business organizations." Id. at 196.

127. 620 F. Supp. 964 (S.D.N.Y. 1985).

128. Id. at 965 (treating a foreign corporation as an LLC without making its reasoning explicit). Section 1332(c)(1) of title 28 of the United States Code provides that a corporation may be treated as a citizen of both the state where it has its principal place of business and the state in which it is incorporated. 28 U.S.C. § 1332(c)(1) (1994). 
the same court later maintained that the holding in Carden had rendered the Great Atlantic opinion inapplicable to an LLC. ${ }^{129}$

Even the Carden opinion itself, however, suggests that there is some judicial support for comparing the LLC to a corporation for purposes of citizenship analysis. The Carden majority went to great lengths to distinguish the case of Puerto Rico v. Russell \& Co. ${ }^{130}$ in which a sociedad en comandita ${ }^{131}$ was treated as a citizen of Puerto Rico for purposes of federal diversity jurisdiction. ${ }^{132}$ A later case, United Steelworkers of America, AFL-CIO v. R.H. Bouligny, Inc., ${ }^{133}$ had distinguished Russell as "fitting an exotic creation of the civil law ... into a federal scheme which knew it not." ${ }^{134}$ The Carden Court therefore concluded, based on the distinction offered in Bouligny:

There could be no doubt ... that at least common-law entities (and likely all entities beyond the Puerto Rican sociedad en comandita) would be treated for purposes of the diversity statute pursuant to what Russell called "[ $\mathrm{t}]$ he tradition of the common law," which is "to treat as legal persons only incorporated groups and to assimilate all others to partnerships." 135

While this statement might seem absolute in its indication that LLCs should not be treated as corporations for purposes of diversity jurisdiction, the dissenting opinion in Carden suggests that a different interpretation of Russell could, in fact, justify applying corporate principles to LLCs. ${ }^{136}$ The Carden dissent noted that the modern limited partnership, like the sociedad en comandita, has its origins in

129. Inarco Int'l Bank N.V. v. Lazard Freres \& Co., No. 97 Civ. 0378(DAB), 1998 WL 427618, at $* 2$ n.6 (S.D.N.Y. July 29, 1998).

130. 288 U.S. 476 (1933).

131. The sociedad en comandita is "the civil law version of the modern limited partnership." Carden, 494 U.S. at 208 (O'Connor, J., dissenting). It is "consistently regarded as a juridical person" that "may contract, own property, and transact business, sue and be sued in its own name and right .... Its members are not thought to have a sufficient personal interest in a suit brought against the entity to entitle them to intervene as parties defendant." Russell, 288 U.S. at 481. Members of a sociedad en comandita may not intervene as defendants in a suit against the sociedad, and the sociedad may endure beyond the death or withdrawal of its members. Id.

132. Russell, 288 U.S. at 482 ("[W]e see no adequate reason for holding that the sociedad has a different status for purposes of federal jurisdiction than a corporation organized under [Puerto Rican] law.”). But see Carden v. Arkoma Assocs., 494 U.S. 185, 189-90 (1990) (referring to Russell as "[t]he one exception to the admirable consistency of our jurisprudence on this matter").

133. 382 U.S. $145(1965)$.

134. Id. at 151.

135. Carden, 494 U.S. at 190 (quoting Russell, 288 U.S. at 480).

136. Id. at 198-209 (O'Connor, J., dissenting). 
the civil law, including the French société en commandite. ${ }^{137}$ The société en commandite was similar to the commenda arrangement common in Mediterranean commerce in the Middle Ages, in which suppliers of capital, who then entrusted it to merchant-seamen, risked only the amount of their capital. ${ }^{138}$ In other words, "[t]he idea of managers being liable without limit while inactive suppliers of capital risked only their capital is ancient." ${ }^{139}$ This historical view indicates that the Russell opinion left room for noncorporate entities, possibly including the LLC (to the extent that it is similar to the limited partnership), to be addressed as corporations for purposes of diversity jurisdiction. ${ }^{14}$

Furthermore, the Carden majority explicitly limited its holding that a noncorporate entity could not be treated like a corporation to those situations involving federal diversity jurisdiction. The basis for the Carden Court's refusal to extend citizenship status to noncorporate entities was not a substantive policy consideration but rather a judgment that the determination of citizenship should be left to the legislature. ${ }^{141}$ In fact, the Carden majority explicitly admitted that its holding could "validly be characterized as technical, precedent-bound, and unresponsive to policy considerations raised by the changing realities of business organization."142 Thus, the LLC could arguably be treated as a corporation in determining citizenship for purposes of federal diversity jurisdiction, although that will most likely not occur "unless and until Congress speaks as to the

137. Id. at 208 (O'Connor, J., dissenting).

138. FORD \& AUSTIN, supra note $101, \S 1.230$.

139. Id.

140. The first attempt to create an LLC in the United States apparently occurred in 1975, when representatives of the Hamilton Brothers Oil Company lobbied the Alaska legislature to authorize a business entity that combined limited liability and partnership tax treatment. Susan Pace Hamill, The Origins Behind the Limited Liability Company, 59 OHIO ST. L.J. 1459, 1464 (1999). The Hamilton Oil Company had used foreign counterparts of the LLC, principally the Panamanian limitada, to conduct oil and gas exploration throughout the 1960s. Id. at 1463 . The Panamanian limitada allowed for limited liability and partnership tax treatment. Id. Hamilton Brothers Oil Company's effort to persuade Alaska to enact legislation allowing a business entity similar to the limitada arrangement failed. Id. at 1464-65 (describing the arguments made before the Alaska legislature and the ultimate failure of the LLC legislation as being due to "political reasons unrelated to the proposals"). Two years later, however, the company succeeded in having the first LLC legislation passed in Wyoming. Id. at 1465.

141. Carden, 494 U.S. at 197 ("[T]he course we take today does not so much disregard the policy of accommodating our diversity jurisdiction to the changing realities of commercial organization, as it honors the more important policy of leaving that to the people's elected representatives.").

142. Id. at 196. 
citizenship of limited liability companies." ${ }^{\text {143 }}$ Regardless, to the extent that neither Congress nor the Supreme Court has explicitly provided a substantive reason why the LLC is not treated as a citizen of the state in which it is incorporated for purposes of jurisdiction, such treatment is not absolutely precluded, particularly for other purposes. The arguments that support applying corporate principles to the determination of the citizenship of the LLC, meanwhile, strengthen the proposition that, like the corporation, the LLC has integrity as an entity that merits respect. ${ }^{144}$

2. Application of the Internal Affairs Doctrine to the LLC. While the LLC has not been treated like a corporation for purposes of citizenship, ${ }^{145}$ neither case law nor statutes explicitly deny that a particular jurisdiction in which an LLC is organized has an interest in having its courts resolve issues affecting the LLC. In contrast, the established internal affairs doctrine recognizes that the state in which a corporation is incorporated does have such a paramount interest regarding corporations: "The internal affairs doctrine requires that the law of the state of incorporation should determine issues relating to internal corporate affairs." ${ }^{146}$ Internal affairs generally include the organizational structure, the relationships between the shareholders and the managers, and the relationships among the shareholders of a corporation. ${ }^{147}$

The internal affairs doctrine furthers several purposes. The doctrine "serves the vital need for a single, constant and equal law to avoid the fragmentation of continuing, interdependent internal relationships." ${ }^{148}$ It does not merely address concerns about forum shopping and notions of territoriality (and in fact operates independently of choice of forum); rather, it "validates the autonomy of the parties in a subject where the underlying policy of the law is enabling. It facilitates planning and enhances predictability." ${ }^{149}$ The internal affairs doctrine also involves issues of constitutional law. The Due Process Clause of the Fourteenth Amendment has, in particular, been interpreted as providing that the directors and officers have a

143. JMTR Enters., L.L.C. v. Duchin, 42 F. Supp. 2d 87, 94 (D. Mass. 1999).

144. See supra notes 127-39 and accompanying text.

145. See supra notes 119-21 and accompanying text.

146. McDermott v. Lewis, 531 A.2d 206, 209 (Del. 1987).

147. P. John Kozyris, Corporate Wars and Choice of Law, 1985 DUKE L.J. 1, 15.

148. Id. at 98 .

149. Id. 
right to know what law will be applied to their actions and that stockholders have a right to know to which standards of accountability a corporation's managers will be held. ${ }^{150}$

The Restatement (Second) of Conflict of Laws recognizes the prevalence of the internal affairs doctrine and provides that "[t]he local law of the state of incorporation will be applied to determine" issues involving the rights and liabilities of a corporation unless "some other state has a more significant relationship to the occurrence and the parties." ${ }^{151}$ This standard differs from that applied to contracts under sections 187 and 188, which generally suggest a contacts test. ${ }^{152}$ This distinction between corporations and contracts is not without criticism. Professor Ribstein, for example, has argued that "[a] residence state does not clearly have a greater 'interest' or other basis for regulating than a contractual state, particularly since the latter may have a strong policy of encouraging selection of its law." ${ }^{153}$ Professor P. John Kozyris, on the other hand, has taken a different approach to whether the internal affairs doctrine should apply to management's fiduciary duties to a corporation and its shareholders; he has proposed that, as between the state of incorporation and the state of principal business, the former has a superior claim because the shareholders are the ultimate beneficiaries of management's fiduciary duties. ${ }^{154}$ Interestingly, the derivative suit brought in Elf Atochem sought to enforce a member's duties to the LLC; ${ }^{155}$ perhaps, then, the state where the LLC was organized, Delaware, had a significant interest in resolving the dispute, either through its courts or through application of its substantive law.

This argument does not really follow from the actual holding in Elf Atochem because there the LLC was not treated as an independent entity whose affairs would necessarily be of interest. Not viewing the LLC as a distinct entity enabled the Elf Atochem court to enforce a choice-of-forum provision against it. The context of this reasoning puts a strange perspective on Professor Ribstein's

150. McDermott, 531 A.2d at 216-17.

151. RestatemEnt (SECOND) OF CONFLict OF LAws $§ 302 \&$ cmt. a (1971).

152. See supra notes $85-92$ and accompanying text. The contacts test generally requires that a court consider the place of contracting; the place of negotiation; the place of performance; the location of the subject matter of the contract; and the domicile, residence, nationality, place of incorporation, and place of business of the parties to determine which law governs the rights and duties of parties to a contract. See supra note 90 and accompanying text.

153. Ribstein, supra note 77, at 256.

154. Kozyris, supra note 147, at 64.

155. See supra note 10 and accompanying text 
argument that the enforcement of choice-of-law provisions in the corporate context has been facilitated by the characterization of the corporation as an entity. ${ }^{156}$ Professor Ribstein has even stated that "corporations are entitled to legal protection because they are contracts, and not because they are 'creatures' of state law." ${ }^{157}$ As demonstrated in Elf Atochem and Bubbles \& Bleach, however, treating an LLC as a contract and not as an entity does not necessarily serve to protect the LLC, perhaps because the courts cannot agree on whether an LLC is something that can be protected.

Delaware courts have, in fact, strongly maintained the distinction between corporations and contracts for purposes of choice of law. In Rosenmiller $v$. Bordes, ${ }^{158}$ for example, the Delaware Court of Chancery explicitly rejected the Supreme Court of Ohio's holding in Gries Sports Enterprises v. Modell. ${ }^{159}$ Gries presented the issue of whether Delaware or Ohio law should apply to a voting agreement between stockholders who, in the aggregate, owned at least $50 \%$ of a Delaware corporation's stock and which was silent as to choice of law. ${ }^{160}$ A majority of the Ohio Supreme Court treated it as a contract issue, not a corporate issue ${ }^{161}$ and applied the contacts test under section 188 of the Restatement (Second) of Conflicts of Law. ${ }^{162}$ The court found that the place of contracting, the place of negotiation, the location of the subject matter of the contract, and the place of business of the parties was Ohio, while only the place of incorporation was Delaware. ${ }^{163}$ Accordingly, it determined that " $[\mathrm{t}] \mathrm{he}$ conclusion is inescapable that Ohio 'bears the most significant relationship to the contract." "164 The court, therefore, reversed a lower court's holding that the law of the state of incorporation governed the agreement. ${ }^{165}$

The Delaware Court of Chancery found the Gries opinion "unpersuasive" and "without any meaningful analysis of the

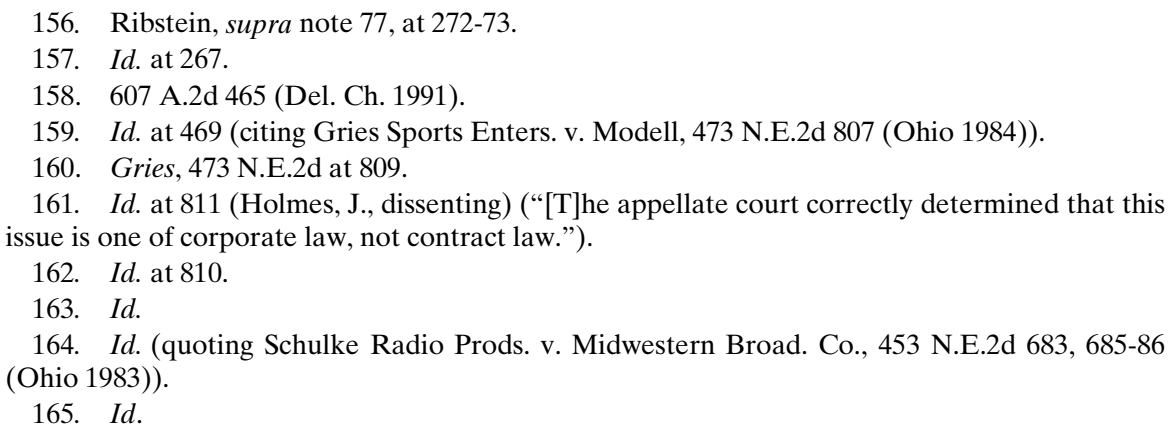


constitutional and corporate law issues that mandate the application of the doctrine of lex incorporationis." ${ }^{166}$ In Rosenmiller, the court applied Delaware law to invalidate the voting restriction provisions of a shareholder agreement on the grounds that the time limit had expired. ${ }^{167}$ The court insisted on applying the internal affairs doctrine even though that decision was outcome-determinative: the agreement explicitly provided that it should be construed under New Jersey law, which would not have limited the agreement to a term of years. ${ }^{168}$

In reaching its holding, the Rosenmiller court emphasized the importance of the internal affairs doctrine. It acknowledged that section 187 of the Restatement calls for enforcing the parties' choice of law "unless the state whose law would control in the absence of a choice has a materially greater interest in the subject matter." ${ }^{169}$ For the Rosenmiller court, the state of incorporation was of great consequence. The court noted that "[i]t is well settled that, under the internal affairs doctrine, the state of incorporation has the paramount interest in having disputes of internal corporate governance resolved according to its own laws." ${ }^{170}$ So much for freedom of contract: the Court of Chancery maintained that the internal affairs doctrine governed the agreement between the stockholders and that the fact that they chose another law did not affect its application. ${ }^{171}$ The Court of Chancery held that, in spite of the choice of law, Delaware's interest in regulating voting rights in Delaware corporations was greater than New Jersey's interest. ${ }^{172}$ The court did not even address the parties' contacts with New Jersey.

Professor Kozyris has offered a potential rationale that may explain the conflict between the Gries and Rosenmiller holdings. He explains that, although the "new conflicts" rules, as seen in sections 302-306 and 309 allow a departure from the internal affairs doctrine

166. Rosenmiller v. Bordes, 607 A.2d 465, 469 (Del. Ch. 1991).

167. Id.

168. Id. at 468-69. The Gries court made a distinction between those cases where the parties had designated a choice of law, as in Schulke and later in Rosenmiller, and those in which they had not. Gries, 473 N.E.2d at 810.

169. Rosenmiller, 607 A.2d at 468 (emphasis added).

170. Id. at 468 (citing Ringling v. Ringling Bros.-Barnum \& Bailey Combined Shows, Inc., 49 A.2d 603, 607 (Del. Ch. 1946)).

171. Id. at 469 ("The present dispute falls squarely within the internal affairs doctrine. The factual circumstance that all voting stockholders chose New Jersey law is not sufficient to remove the dispute from that doctrine.").

172. Id. ("Delaware therefore has a greater interest than does New Jersey in regulating stockholder voting rights in Delaware corporations."). 
where another state has a more significant relationship to the corporation, shareholders, or parties, courts almost always apply the law of the state of incorporation without any discussion. ${ }^{173}$ As it applies to corporations, the internal affairs doctrine still serves to protect any interest the state of incorporation has in its affairs.

The doctrine of internal affairs could arguably be applied to the LLC as well as to the corporation to protect any interest that the state of the LLC's organization has in the LLC. Some state LLC statutes explicitly adopt the internal affairs doctrine, such that the internal affairs of the LLC are subject exclusively to the laws of the state of formation. ${ }^{174}$ The Delaware Limited Liability Company Act, for example, provides that "[t]he laws of the state... under which a foreign limited liability company is organized govern its organization and internal affairs and the liability of its members and managers." ${ }^{175}$ Even in the absence of such a statutory directive, however, policy concerns could justify the extension of the internal affairs doctrine from the corporation to the LLC. ${ }^{176}$ First, as Professor Kozyris has argued, for purposes of conflict-of-laws determinations, the LLC bears considerable similarities to the corporation. ${ }^{177}$ The LLC is like a corporation in that it offers limited liability and continuity of life. ${ }^{178}$ Furthermore, while an LLC is unlike a corporation in having decentralized management and limited transferability of interests, those characteristics are relatively unimportant for purposes of conflict of laws. ${ }^{179}$

Second, LLC law suggests that the LLC historically has been treated like a corporation for purposes of limited liability. An initial

173. Kozyris, supra note 147, at 17-18 (noting that the law of the state of incorporation has been applied in all but a "handful of cases" over the last twenty-five years).

174. Kozyris, supra note 114, at 568 (citing ARK. CODE ANN. § 4-32-1001 (Michie Supp. 1993); CAL. CORP. CODE $§ 17,450$ (a) (West Supp. 1995); IDAHO CODE $§ 53-650$ (1993); WIS. STAT. ANN. § 183-1001 (West Supp. 1994)).

175. Del. CODE ANN. tit. 6, § 18-901(a)(1) (1997).

176. Professor Kozyris described those statutes directing the application of the internal affairs doctrine to an LLC as "unnecessary" because such directives are "completely consistent with conflict-of-laws theory and practice." Kozyris, supra note 114, at 568.

177. Id. at 570 (noting that the "LLC is a hybrid form of a corporation and a partnership").

178. Id.

179. Id. ("Decentralized management and limited transferability of interests do not appear to be important characteristics under the conflict-of-laws lens."). Professor Kozyris also points out that many closely held corporations have limited transferability of interests and decentralized management but are nonetheless subject to the internal affairs doctrine. Id. Interestingly, Professor Kozyris additionally assimilates the LLC to the corporation in characterizing both as "legal persons," although, as this Note demonstrates, the LLC is not necessarily treated as such. Id. 
concern with the LLC was that states that did not recognize the organizational form of the LLC would construe an LLC as a general partnership and, accordingly, impose unlimited liability upon the LLC's members. ${ }^{180}$ Thus, at the earlier stages of the development of LLC law, it was urged that "[c]orporate precedents appear to be the appropriate analogy for determining whether LLC members are entitled to limited liability in intrastate and interstate LLC transactions." of the state of organization would govern member liability. ${ }^{182}$ Beyond that, courts and scholars cited the Restatement of Conflict of Laws, the common law principle of comity, the Full Faith and Credit Clause, and the Interstate Commerce Clause for the proposition that, in actions against an LLC in a foreign jurisdiction, the court should treat the LLC as a corporation and apply the limited-liability provisions of the LLC's state of organization. ${ }^{183}$ This concern might be outdated now that every state recognizes some type of LLC and might relate more to the problem of liability to third parties as opposed to interaction between the members. Given the limited application of the internal affairs doctrine to issues regarding limited liability, the strange position in which the modern LLC finds itself-an entity for liability purposes but apparently not for others, at least not in Delaware-is not all that surprising. Regardless, the past willingness to recognize the application of the internal affairs doctrine to the LLC, even for particular purposes only, and the recognition of similarities between the corporation and the LLC indicate that the LLC should merit some protection as an entity.

\section{THE CONTINUING IMPACT OF DEMAND}

Application of the internal affairs doctrine to an LLC would suggest that the state of organization has some interest in having disputes involving the LLC resolved according to its laws. ${ }^{184}$ This observation raises the question why the Delaware Supreme Court seemed comfortable allowing Malek LLC's affairs to be determined by arbitrators in California. In support of its view that Malek LLC

180. Id. at 565 .

181. Keatinge et al., supra note 1 , at 456.

182. Id. (noting that the law of the state of organization governs member liability in Colorado, Kansas, Virginia, and Texas).

183. Id.

184. See supra notes $174-82$ and accompanying text. 
was subject to arbitration in California, the Elf Atochem court cited numerous Delaware cases that expressed the state's favorable view of arbitration, ${ }^{185}$ the court did not, however, consider whether the arbitration provisions in question in the cited cases also involved a choice of forum other than Delaware. In fact, the provisions at issue in those cases did not contain any express reference to a choice of forum other than Delaware. Furthermore, the claims brought in Elf Atochem were arguably within the "internal affairs" of the LLC, and as such the Delaware Supreme Court conceivably could have insisted on applying its own law. As Professor Susan Pace Hamill notes, the LLC's "earliest origin" stems from "the cementing of state power over the creation of corporations."

Attracting business to the state drove the enactment of LLC legislation. Wyoming enacted the first LLC legislation in $1977,{ }^{187}$ and Florida followed in $1982 .{ }^{188}$ The purpose of these initial enactments was to attract capital into the respective states. ${ }^{189}$ Since a 1989 announcement by the Internal Revenue Service that a lack of personal liability would not preclude an entity's classification as a partnership for tax purposes, ${ }^{190}$ the other forty-eight states and the District of Columbia have each enacted limited liability company legislation. ${ }^{191}$

185. Elf Atochem N. Am., Inc. v. Jaffari, 727 A.2d 286, 292 n.34 (1998) (citing SBC Interactive, Inc. v. Corporate Media Partners, 714 A.2d 758, 761 (Del. 1998); Graham v. State Farm Ins. Co., 565 A.2d 908, 911 (Del. 1989); Action Drug Co. v. R. Baylin Co., No. 9383, 1989 Del. LEXIS 74, at *3 (Del. Ch. June 19, 1989); Pettinaro Constr. Co. v. Harry C. Partridge, Jr. \& Sons, Inc., 408 A.2d 957, 961-63 (Del. Ch. 1979)).

186. Hamill, supra note 140, at 1462.

187. Keatinge et al., supra note 1, at 383 .

188. Id. (citing Fla. STAT. ANN. 608.401-.471 (West Supp. 1991)).

189. Keatinge et al., supra note 1 , at 383 .

190. Id. at 384 (noting that the announcement stated the Internal Revenue Service's intention to treat a Wyoming LLC as a partnership for tax purposes).

191. Ala. CoDE $\S \S 10-12-1$ to -61 (1999); ALASKa STAT. $§ \S 10.50 .010-.995$ (Lexis 1998 \& Supp. 1999); ARIZ. Rev. StAT. ANN. §§ 29-601 to -857 (West 1998 \& Supp. 1999); ARK. CodE ANN. §§ 4-32-101 to -1401 (Michie 1996 \& Supp. 1999); CAL. CoRP. CODE $\S 17,000-17,655$ (West Supp. 2000); Colo. Rev. Stat. §§ 7-80-101 to -1101 (2000); Conn. Gen. Stat. AnN. $\S \S 34-100$ to -299 (West 1997 \& Supp. 2000); DEL. CODE ANN. tit. 6, §§ 18-101 to -1109 (1999); D.C. Code AnN. §§ 29-1301 to -1375 (1996 \& Supp. 2000); FlA. STAT. AnN. §§ 608.401-.703 (West 1993 \& Supp. 2000); GA. CODE ANN. §§ 14-11-100 to -1109 (1994 \& Supp. 2000); Haw. REV. STAT. ANN. \$§ 428-101 to -1302 (Michie 1997 \& Supp. 2000); IDAHo CODE §§ 53-601 to -672 (Michie 1994 \& Supp. 2000); 805 Ill. Comp. Stat. AnN. 180/1-1 to 180/60-1 (West Supp. 2000); Ind. Code AnN. §§ 23-18-1-1 to -13-1 (Michie 1999 \& Supp. 2000); Iowa Code AnN. $\S \S$ 490A.100-.1601 (West 1999 \& Supp. 2000); KAN. STAT. ANN. §§ 17-7601 to -7709 (1995 \& Supp. 1999); Ky. Rev. StAT. ANN. §§ 275.001-.455 (Banks-Baldwin Supp. 1999); LA. Rev. StAT. ANN. §§ 1301-1369 (West 1994 \& Supp. 2000); ME. REV. Stat. ANN. tit. 31, §§ 601-762 (West 1996 \& Supp. 1999); MD. COdE ANN., CoRPS. \& Ass’NS §§ 4A-101 to -1103 (1999 \& 
The driving force behind this recent rise in the number of LLC statutes was largely a desire to avoid limitations on the single-tax treatment of S corporations ${ }^{192}$ while enjoying limited liability. ${ }^{193}$ Much of the language of LLC statutes borrows from the law of partnership and closely held corporations. ${ }^{194}$ More recently, however, flexibility has dominated LLC statutes and allowed drafters of LLC agreements greater rein. ${ }^{195}$ This flexibility has affected more than just tax considerations: adherence to principles of freedom of contract now characterizes much of LLC law. ${ }^{196}$

Supp. 2000); MASS. GEN. LAws ch. 156C, §§ 1-68 (1996 \& Supp. 2000); Mich. Comp. LAws ANN. §§ 450.4101-.5200 (West Supp. 2000); MinN. STAT. ANN. §§ 322B.01-.960 (West 1996 \& Supp. 2000); Miss. CODE ANN. § 79-29-101 to -1204 (2000); Mo. ANN. STAT. §§ 347.010-.740 (West Supp. 2000); Mont. Code AnN. §§ 35-8-101 to -1307 (1999); Neb. REV. Stat. §§ 212601 to -2653 (Michie 1999 \& Supp. 2000); NEV. REV. STAT. ANN. 86.010-86.590 (Michie 1999); N.H. REV. STAT. ANN. §§ 304-C:1 to 304-C:85 (1995 \& Supp. 1999); N.J. STAT. ANN. §§ 42:2B-1 to -70 (West Supp. 2000); N.M. STAT. ANN. §§ 53-19-1 to -74 (Michie 1993 \& Supp. 1999); N.Y. LTD. Liab. Co. Law §§ 101-1403 (McKinney Supp. 2000); N.C. GEN. STAT. §§ 57C-1-01 to -1007 (1999); N.D. CENT. Code §§ 10-32-01 to -156 (1995 \& Supp. 1999); OHIO ReV. Code ANN. $\S \S 1705.01-.58$ (West 1993 \& Supp. 2000); OKLA. STAT. ANN. tit. 18, §§ 2000-2060 (West 1999 \& Supp. 2000); OR. Rev. STAT. §§ 63.001-.990 (Supp. 1998); 15 PA. Cons. Stat. AnN. §§ 89018998 (West 1995 \& Supp. 2000); R.I. GEN. LAws §§ 7-16-1 to -75 (1999); S.C. CODE ANN. §§ 3344-101 to -1207 (Law. Co-op. Supp. 1999); S.D. CodIFIED LAws §§ 47-34A-101 to -1207 (Michie 2000); Tenn. Code AnN. \$§ 48-201-101 to 48-248-606 (1995 \& Supp. 1999); TeX. Rev. Civ. Stat. ANN. art. 1528n, $\S \S 1.01-11.07$ (Vernon 1997 \& Supp. 2000); UTAH CodE ANN. $\S \S 48-2 b-101$ to -158 (1998 \& Supp. 2000); VT. STAT. ANN. tit. 11, §§ 3001-3162 (1997 \& Supp. 2000); VA. Code AnN. §§ 13.1-1000 to -1073 (Michie 1999 \& Supp. 2000); WASH. REv. Code ANN. §§ 25.15.005-.902 (West Supp. 2000); W. VA. CoDE ANN. §§ 31B-1-101 to 31B-13-1306 (Michie 1996 \& Supp. 2000); WIS. STAT. ANN. §§ 183.0102-.1305 (West Supp. 1999); WYO. STAT. ANN. §§ 17-15-101 to -144 (Michie 1999 \& Supp. 2000).

192. Kozyris, supra note 114 , at 574

193. Gazur, supra note 1, at 166 .

194. Id. at 135; see also Keatinge et al., supra note 1, at 395 (suggesting that "it is important to compare LLCs with statutory close corporations"). State legislatures presumably believed that the business relationships for which an LLC is suited resembled those of a partnership or closely held corporation. Gazur, supra note 1, at 135 (citing Scott R. Anderson, The Illinois Limited Liability Company: A Flexible Alternative for Business, 25 LOY. U. CHI. L.J. 55, 103-04 (1993); Keatinge et al., supra note 1, at 395).

195. Gazur, supra note 1 , at 143 .

196. An LLC agreement or operating agreement is a contract that sets forth provisions for the operation and governance of the LLC. Delaware, for example, defines a limited liability company agreement as "any agreement, written or oral, of the member or members as to the affairs of a limited liability company and the conduct of its business." DEL. CODE ANN. tit. 6, $\S 18-101(7)$ (1999). Virginia similarly defines "operating agreement" as "an agreement of the members as to the affairs of a limited liability company and the conduct of its business." VA. CODE ANN. § 13.1-1002 (Michie 1999). For other similar definitions of what constitutes an LLC agreement, see the Uniform Limited Liability Company Act, UNIF. LTD. LiAB. Co. ACT $\S 103(a), 6$ A U.L.A. 434 (1995) (“[A]11 members of a limited liability company may enter into an operating agreement ... to regulate the affairs of the company and the conduct of its business, and to govern relations among the members, managers, and company."), the California Corporate Code, CAL. CORP. CODE $\S 17,001(\mathrm{ab})$ (West Supp. 2000) (“'Operating agreement' means any agreement, written or oral, between all of the members as to the affairs of a limited 
The Elf Atochem court itself characterized the LLC as "an attractive vehicle to facilitate business relationships and transactions." 197 The Elf Atochem decision raises the issue as to what effect enforcing choice-of-forum provisions in an LLC agreementand what effect doing so when the LLC is not expressly a party to the agreement-will have on the attractiveness of forming an LLC in a particular state. For example, a court could construe Elf Atochem as allowing an arbitration award to be enforced against a defendant LLC that was not a party to an arbitration agreement in a dispute that was submitted to arbitration over the LLC's objections. Such a policy might discourage the formation of an LLC in a particular state.

In advocating the enforcement of contractual choice-of-law provisions generally, Professor Ribstein has postulated that permitting parties to choose the governing law gives states an incentive to compete for legal business. ${ }^{198}$ The competition for legal business influences states to develop new laws to attract new business and revise laws to retain business, which in turn leads to efficient legal rules. ${ }^{199}$ Both a state and interest groups within it can benefit from having efficient legal rules such as the kind spurred by competition; ${ }^{200}$ in particular, a state can increase its revenue if enforcing choice-oflaw provisions attracts business to the state or allows the state to collect a fee for contracts that choose the state's law. ${ }^{201}$

Of course, this argument addresses whether parties would choose a state's law in the first place, not whether a state's tendency to enforce choice-of-law provisions makes it competitive. Interestingly, however, Professor Ribstein cites the development of LLC laws as evidence of the potential beneficial effect of jurisdictional competition; more recent statutes, for example, allow greater flexibility in an LLC agreement's provisions for continuing the firm after dissociation and on transferring interests. ${ }^{202}$ While Professor Ribstein admits that the development of LLC law might have occurred without enforcing contractual choice of law because most

\footnotetext{
liability company and the conduct of its business ...."), and the New York Limited Liability Company Law, N.Y. LTD. LiaB. Co. LAw § 102(u) (McKinney Supp. 2000) (“'Operating agreement' means any written agreement of the members concerning the business of a limited liability company and the conduct of its affairs ....").

197. Elf Atochem N. Am., Inc. v. Jaffari, 727 A.2d 286, 287 (Del. 1999).

198. Ribstein, supra note 77, at 249.

199. Id. at $249-50$.

200. Id. at $259-60$

201. Id. at 259.

202. Id. at 250 .
} 
LLCs are organized under the state where their business is located, ${ }^{203}$ he argues that the rapidity of its development "is a sign that legislatures and bar groups acted at least to some extent in response to potential competition from other states."204

Competition among states for LLCs is still certainly possible. As of yet, no state has strongly drawn interstate LLCs the way Delaware has attracted corporations. ${ }^{205}$ Nonetheless, to the extent that the differences among states in the degree of freedom given to parties to fashion their own arrangement are important to those organizing LLCs, those differences will most likely create preferences among states. ${ }^{206}$ Furthermore, many legislators and LLC promoters at the state level perceive their LLC statutes as attracting and keeping business and investment in their particular state. ${ }^{207}$ This pressure contributes to the multistate contest for LLC business. ${ }^{208}$

In the face of this competition, Delaware is potentially preeminent. $^{209}$ "Already a forum of choice when it comes to organizing corporations, limited partnerships and business trusts, the state [Delaware] intends to achieve a comparable position" for LLCs. ${ }^{210}$ In less than a decade, over 100,000 LLCs have been formed in Delaware, in contrast to approximately 290,000 corporations. ${ }^{211}$ The flexibility of the Delaware statute contributes to Delaware's potential preeminence in that it makes Delaware LLCs amenable to the "special tailoring" that is often needed for complex business organizations. ${ }^{212}$ In addition, Delaware has sought to facilitate the transfer of non-Delaware organizations into Delaware by allowing them to domesticate as, or convert into, Delaware LLCs without having to go through a merger. ${ }^{213}$

\footnotetext{
203. Id.; see also Kozyris, supra note 114, at 567-68 (contrasting the LLC statutes of different states).

204. Ribstein, supra note 77 , at 250 .

205. Kozyris, supra note 114 , at 567-68.

206. Gazur, supra note 1, at 147

207. Id. at 179 .

208. Id.

209. See Kozyris, supra note 114 , at 567.

210. Leyden, supra note 97 , at 51.

211. Id. IRS statistics indicate that, in 1997 , there were some 4,787,000 corporations filing returns nationwide. Number of Business Income Tax Returns, by Size of Business for Specified Income Years, 1980-1997, http://www.irs.gov/prod/tax_stats/soi/other_nr.html (on file with the Duke Law Journal).

212. RIBSTEIN \& KEATINGE, supra note 53, § 14.01[1].

213. Id. $\S 14.01[1]$ n.4. Sections $18-212$ and 18-214 provide for the domestication or conversion of organizations from non-United States jurisdictions and other state jurisdictions,
} 
The Delaware LLC Act was once characterized as "designed to preserve the primacy of Delaware judges in interpreting and making Delaware LLC law." 214 The support for this statement came in part from section 18-109 of the Act, which provides:

In a written limited liability company agreement or other writing, a manager or member may consent to be subject to the nonexclusive jurisdiction of the courts of, or arbitration in, a specified jurisdiction, or the exclusive jurisdiction of the courts of the State of Delaware, or the exclusivity of arbitration in a specified jurisdiction of the State of Delaware.... ${ }^{215}$

In arguing that the Delaware statute was drafted to promote the preeminence of Delaware in LLC law, Professors Ribstein and Keatinge interpreted this section as allowing parties to agree to exclusive jurisdiction only in the courts of Delaware. ${ }^{216}$ The Elf Atochem court, however, interpreted this section somewhat differently, stating the statute does not expressly prohibit the parties from vesting exclusive jurisdiction in court proceedings in another jurisdiction. ${ }^{217}$ Another plausible argument is that, because the Delaware General Assembly specifically allowed for the exclusive vesting of jurisdiction in Delaware courts while only providing for nonexclusive jurisdiction in non-Delaware courts, it did not intend to

respectively.

214. Id. § 14.01[1] n.4. In discussing the role of Delaware courts in LLC law, James G. Leyden, Jr. has noted that, "The Court of Chancery and the Supreme Court are the same courts that often handle Delaware corporate, limited partnership and business trust litigation and have substantial experience in resolving business disputes." Leyden, supra note 97, at 63. He goes on to offer a possible insight into another reason why a Delaware court might enforce an operating agreement against a nonparty LLC:

The Delaware courts have recognized, for example, that many partnership agreements are drafted by sophisticated commercial lawyers and the Delaware courts attempt to give effect to the words used in the partnership agreement. It is likely that Delaware courts will take a similar view when interpreting DLLC agreements and the rights and duties of members and managers.

Id.

215. Del. Code AnN. tit. 6, § 18-109(d) (West 2000).

216. RibSTEIN \& KeAtinge, supra note 53, § 14.01[1]. At the time of Ribstein and Keatinge's publication, section 18-109 read, "[i]n a written limited liability company agreement or other writing, a manager or member may consent to be subject to the nonexclusive jurisdiction of the courts of, or arbitration in, a specified jurisdiction, or the exclusive jurisdiction of the courts of, or the exclusivity of arbitration in, the State of Delaware...." Thus, Ribstein and Keatinge's statement should be revised to read that parties may agree to the jurisdiction of courts only in Delaware but of arbitration in any jurisdiction.

217. Elf Atochem N. Am., Inc. v. Jaffari, 727 A.2d 286, 296 (Del. 1999). 
permit vesting exclusive jurisdiction in the courts of another jurisdiction. In promoting freedom of contract in LLC agreements, perhaps in an attempt to make Delaware attractive for organizers of LLCs, the Elf Atochem decision might actually have sacrificed some of the control the state can exercise over LLCs. The Elf Atochem opinion could be construed as suggesting that a state does not have a paramount interest in the operation of its LLCs: first, because it intimates that an LLC is not an entity in which the state necessarily has an interest, and, second, because it permits issues concerning its LLCs to be resolved in another forum. ${ }^{218}$

\section{CONCLUSION}

Freedom of contract offers a business entity flexibility in organizing its structure and conducting its affairs. Arbitration policy now gives arbitration agreements equal footing with other contracts. These principles notwithstanding, the enforceability of an arbitration agreement against a party requires a preliminary determination that the party is in fact a party to the agreement.

This determination becomes complicated when the party in question is an LLC. The LLC is an amalgam of partnership and corporate characteristics. As such, a court could arguably treat the LLC as a conglomeration of its members, like a partnership. In this case, all of the members could bind the LLC to their own agreement to arbitrate. Application of the conflicts of laws principles governing partnerships in fact suggests that an LLC should not expect to have its disputes resolved in courts of its state of formation.

A court could treat the LLC as an independent entity, like a corporation. Application of the citizenship and internal affairs doctrines used in corporations law indicates that freedom of contract does not necessarily justify enforcing a contract to which an LLC is not a party against it. Citizenship analysis indicates that treating an LLC in the same way as a corporation for purposes of diversity jurisdiction is within the power of the legislature. To the extent that an LLC is like a corporation, it could benefit from the principles expressed in the internal affairs doctrine, which explicitly recognizes that the state of formation has an important interest in having its

218. James G. Leyden, Jr. has noted that the majority of Delaware LLCs do not conduct business in the state and have no assets or activities there other than the required maintenance of a registered agent and office but are formed in Delaware to benefit from the state's laws and courts. Leyden, supra note 97, at 63. 
[Vol. 50:1087

courts resolve issues affecting the corporation. LLC legislation grew out of state legislatures' desire to attract business to their respective states. A willingness to bind an LLC to an agreement to which it is not a party, however, might counter the attraction offered by a form of business association as flexible as the LLC. In this respect, enforcing such contracts could harm not only the LLC but also the state that enforces them. 